\title{
HOME THOUGHTS, FROM ABROAD: THE FANTASY OF "BLIGHTY," THE REALITY OF HOME
}

\author{
Michael Hollington, Clare Hall, Cambridge University, \\ wahlverwandschaften@gmail.com
}

DOI: 10.31902/fll.31.2020.2

UDK 821.111.09

\begin{abstract}
This paper examines the frequent use of the word 'blighty' in First World War poetry and prose to signify from the frontline trenches the longedfor world of home. A word of Anglo-Indian origin, the product of folk etymology, as unlettered soldiers convert 'bilayati' meaning 'foreign' into something that sounds more familiar in English, it retains its association with the speech of the common soldier in First World War poetry. It modulates in meaning, as the war gets increasingly desperate, and starts in poetry and elsewhere to refer to a relatively minor wound that will get you back home and out of the war. I examine this shift in a number of poets, notably Owen, Sassoon, and Gurney. I also examine the experience of 'blighty' from the other end of the telescope, so to speak. That is to say, from the perspective of women writers receiving their men at home and bidding them farewell for the last time. I illustrate such writing in the distinguished novel World Without End by Helen Thomas, the widow of the war poet Edward Thomas.
\end{abstract}

Keywords: "Blighty," Anglo-Indian culture, World War I, poetry, Home Front

The word "Blighty," which had its heyday between 1914 and 1918 on the battlefields of World War 1, as a signifier among anglophone troops for the absent, ardently longed for world of home in England or elsewhere, is a curious example of the fascinating and often amusing linguistic category of the "folk etymology." The term, a translation of the German Volksetymologie coined by Emil Förstemann in 1852, denotes, to quote Wikipedia, "a change in a word or phrase resulting from the replacement of an unfamiliar form by a more familiar one": that is, through a process in which "the form or the meaning of an archaic, foreign, or otherwise unfamiliar word is reanalyzed as resembling more familiar words or morphemes" (https://en.-wikipedia.org/wiki/Folk etymology).

Thus, to give a few examples, the English word "cockroach" is a rehandling of the Spanish word "cucuracha," and "Jerusalem artichokes" of the Italian "girasole" - and, conversely, the French "redingote" is a version of "riding coat." Place-names are often 
corrupted in the same way - thus, the English name "Leghorn" for an Italian town has nothing to with legs or horns, but is simply a way or making the name "Livorno" more familiar to anglophone ears. Football supporters struggling with the unfamiliar names of foreign teams provide some authentic and amusing contemporary examples - thus "Twente Enschede," which comes from the Dutch region where the Germanic tribe of the Tuihanti are thought to have settled, has of course been appropriated as "Twenty" in English, and when Newcastle defeated the Budapest team Ujpest Dozsa in the final of the 1969 European Fairs Cup their opponents were dubbed "Oopsy Daisy."

This last example in particular suggests that humour is often a feature of such coinages, derived from a perception of unexpected and incongruous relationships between languages. Indeed, nowadays in the age of mass tourism it is a pastime which all of us can enjoy. Travellers regularly joke as they encounter foreign words that invite ribald puns - Cuir Centre, the leather furniture chain in France, easily becomes Queer Centre, and Norwegian hoardings that advertise mints with the message "frisk i munnen" (fresh in the mouth) naturally suggests friskiness. This humorous element is certainly often prominent in the case of the word "Blighty," but it in fact carries a whole gamut of associations, from biting humour and bitter irony at one end of the spectrum to transcendent suggestions of paradise at the other. It is to be thought of not at all as a literary concept, in its origins at least, but as a word stemming from the common people. This is often signalled by poets like Sassoon and Owen, who belonged to the class of officers and gentleman, who treat it as a distinctive feature of the common language of infantrymen, not of the more cultivated dialect of their own tribe.

As such it finds its quintessential expression in one of the ballads sung by troops as they matched along at the front, made famous above all in 1917 by the music-hall star Florrie Forde. "Take me back to Dear Old Blighty" posits in humorous vein a radical contrast between battlefield front and the familiar lost world of home, of a kind we see echoed in many of the writers discussed below:

Jack Dunn, son of a gun, somewhere in France today,

Keeps fit doing his bit, up to the eyes in clay

Each night after a fight to pass the time along

He's got a little gramophone that plays this song:

Take me back to dear old Blighty

Put me on the train for London town

Take me over there 
Drop me anywhere,

Birmingham, Leeds, or Manchester, well I don't care

I should love to see my best girl

Cuddling up again we soon should be (whoa!)

Tiddly-iddly-itey

Hurry me back to Blighty

Blighty is the place for me!

One day, Mickey O'Shea, out in a trench somewhere, So brave, having a shave, trying to part his hair

Mick yells, dodging the shells and lumps of dynamite:

'Talk of the Crystal Palace on a firework night!'

Take me back to dear old Blighty

Put me on the train for London town

Take me over there

Drop me anywhere,

Birmingham, Leeds, or Manchester, well I don't care

I should love to see my best girl

Cuddling up again we soon should be (whoa!)

Tiddly-iddly-itey

Hurry me back to Blighty

Blighty is the place for me!

(https://www.youtube.com/watch?v=nRsO7tCjhAA)

The humour here, and often elsewhere when the word "Blighty" is used, I think, can be seen as a mask for deeper feelings than the jaunty, cheerful music would suggest. Its strangeness and exoticism serve as a distancing device against the emotional charge that might be triggered by much more deep-rooted words of AngloSaxon origin like "home."

But back to its own Anglo-Indian origins. These may be sought in the famous 1886 Anglo-Indian dictionary by Yule and Coke, the Hobson-Jobson - itself a folk etymology, a word meaning festival or entertainment that is a corruption by British soldiers of the chant of "Yā Hasan! Yā Hosain!" heard at the Shia Muslim festival of Muharram: in English, "folk etymology" is in fact sometimes referred to as "the law of Hobson-Jobson." For it is a word like many others, including "bungalow," "jungle," "loot," and "pyjamas," that comes into English from India, and specifically from the period of the British raj in the $19^{\text {th }}$ century. There in the Hobson-Jobson, in the entry for "Bilayut, Billait," we find that the word has the general meaning of "Europe," and is ultimately derived from Arabic "wilayati," meaning "province" or 
"kingdom." Initially the primary reference is to one's own kingdom or province, but in the process of assimilation into India via Turkish and Afghan it came to mean "foreign land," and particularly Europe, above all of course Britain - "home," of course, to the British soldiers stationed there (Yule and Burnell 98).

Thus, a group of signifiers in Urdu or Hindi or Bengali (including "Belaiti" as well as "Bilayut" and "Billait"), frequently heard or misheard by British soldiers serving in India, got corrupted into the English-sounding "Blighty" (Yule and Burnell $x$ ). The first surprise this process contains is that the word that in the first world war would mean the beloved homeland is derived from a source where it has completely opposite connotations of foreignness and otherness. Kipling, who of course knew and loved India in a way that few others did, in fact uses it in its original Indian sense and spelling in his satiric story "Griffiths the Safe Man," in connection with a man obsessed with locks and keys, who looks down on the Japanese - quite absurdly, it appears, for, just like him, "every Japanese carries a little belaiti-made handbag with nickel fastenings" (Kipling 30).

But this ambiguity soon gives way to a greater one. It is clear that the primary sound that British soldiers heard in the Urdu or Bengali or Hindi references to Britain surrounding them was that belonging to the thoroughly negative word "blight," with the literal meaning of a canker or disease of plants, not uncommonly used metaphorically in human contexts as well, especially in the colloquial name for someone who annoys or irritates you, a "blighter" - another item of slang whose usage peaks around the period of the First World War, with uncomfortable reminders of the holy word "Blighty."

One further detail needs to be added about it- again involving humour of a grim kind - before we can begin to look at some literary examples of its use. During the course of its evolution during the terrible years of 1914-1918, it came to be used metonymically, not only as a name for "home" but as a name for the means whereby a soldier at the front might get there. That is to say, "Blighty" becomes a word that also signifies a wound not serious enough to result in permanent disablement but sufficiently serious to get you sent back to "Blighty" for treatment. (And in the context of the horrors of this war, it is hardly surprising that some would resort to desperate measures to achieve this end - sticking one's hand above the parapet, for example, to get a finger or two blown off, or shooting oneself in the foot through a sandbag - despite the possibility of the death penalty as a punishment for proven cases of self-harm.) Indeed, the more one looks at the use of the word in First World War writing the more it begins to 
seem that this secondary usage gradually takes over at the front as the primary one. For the men at the front, "Blighty" itself in its more exalted meanings becomes an ever more distant mirage, whereas wounds of all shapes and sizes are at all times everywhere about them. Even at an early stage of the war, perhaps, instances of the use of the word "Blighty" that connote a haven of bliss and safety from war are rare. In a novel written long after its end, like many of the most important writings on the war, Ford Madox Ford in The Marsden Case provides an example. An anonymous soldier remembers hearing the voice - not of Florrie Forde, but of the fictional Clarice Honeywill - at the front in Hazebrouck, and being vouchsafed thereby a vision of Blighty that calms his shattered nerves: "it was like being in a tea-shop: in Blighty. I don't suppose you know: from the Bible: 'Yet with angels and archangels.' It was like that. A turning point. It seemed to give me courage, and that has lasted" (MC II, vii, 272).

Yet such exalted evocation of the world of home is undercut by the sardonic pair of sentences with which the passage concludes: "He was a simple soul. He is dead now." Elsewhere, in Robert Graves's Goodbye to All That, for instance, the yearning for "Blighty" at the front is presented in a much more hard-bitten way. He asserts roundly that "there was no patriotism in the trenches," and that "as Blighty Great Britain was a quiet, easy place to get back to out of the present foreign misery, but as a nation it was nothing" (Graves xvii, 239). In Ivor Gurney's "The Estaminet" from Severn and Somme of 1917, there are two uses of the word in its conventional sense in a poem about soldier's conversations in a bar at the front that corroborate Graves: "We spoke no word of glory/ Nor mentioned 'foreign yoke'." Blighty is indeed the longer-for place ("O! that we were there!"), but what it represents is merely "yarns of girls in Blighty" of a thoroughly unidealistic kind, with words like "vain" and "ugly" to qualify the girls, or "standoffish, foolish, flighty," to rhyme of course with "Blighty." In the last stanza, the poet imagines he might get to Blighty - "or hell," he adds. In either case he will be deprived of "the flood of love that filled me" for these comrades, either because he is dead or because they are (SS 40-41).

But Gurney is representative of many in his greater enthusiasm for using the word to refer to a life-saving wound. In the fine "Ballad of the Three Spectres" in Severn and Somme the poet conjures up a vision of three skeletons in the medieval tradition of "les trois vifs et les trois morts" (as at Longthorpe Tower in the Soke of Peterborough - see Pevsner 288) who predict the outcome of his engagement in the war. Only the first of them has anything at all positive to say, conjuring up 
an image of him "on a fine stretcher/ And laughing for a nice Blighty" a vision angrily rejected as the soldier remains fit and alive and waiting to see if the third of them "spake verity" in foretelling that "he'll stay untouched till the war's last dawning/ Then live one hour of agony." Alas, Gurney's fate was yet worse that this prediction - he suffered a mental breakdown after the war and spent the rest of his life in an asylum, until his death in 1937 (CP 33-34).

These poems clearly reflect attitudes that emerge from Gurney at first hand in his letters from the front. In War Letters, R. K. R. Thornton tentatively assigns to late June/early July 1917 a letter to Marion Scott that again dismisses any talk of heroism on the battlefields of the Somme. "Who will dare talk of the glory of Waterloo or Trafalgar again?", he writes, swearing "May God forgive me ... if I lie later to younger men of the Great Days. It was damnable..." "Men die and are left to rot because of snipers. It might be me tomorrow. Who cares? Yet still, hang on for a Blighty." As he prepares to go into the Blockhouse and face further danger, he prays only that he "may get a Blighty doing so... and $O$ if it were but a small hole in the leg!" (WL 171) Yet stronger attitudes are expressed in the poetry of Siegfried Sassoon, who also longed for a "Blighty" in this sense in order to enjoy the real "Blighty" of being at home with his mother, as Jean Moorcroft Wilson observes: "One of Sassoon's strongest temptations to give in to a 'Blighty' had been the thought of home, of his mother coming in with roses from the garden, of his dog Topper, his book-lined study and his piano" (Wilson 514). But such an image of "Blighty" as a paradise in an upper-middle class home is dwarfed in his work by its other sense, which he, as suggested above, sees from the perspective of an army officer as specifically class-bound, belonging essentially to the common soldier. In the poem "Stand-To: Good Friday Morning," the soldier/speaker offers in doggerel to do a deal with God - a Blighty for belief, as in Graham Greene's The End of the Affair: "Jesus, send me a wound today, / And I'll believe in your bread and wine" (War Poems 22). In another poem, class divisions are explored through the medium of musical taste, contrasting "great names" like those of Bach, Mozart and Beethoven with the popular songs about Blighty sung at the front by the ordinary men under his command, of which "Take me back to Dear Old Blighty" is the classic example. "I cannot find you now," he declares to the former, "Your fugues and symphonies have brought/ No memory of my friends who died," and in order to reach these dead men he has to go to a quite different register of rag-time and syncopation: "They've got such jolly things to tell/ Home from hell with a Blighty wound so neat" (Wilson 441). 
The same idea of addressing God at the front in the hope of doing a deal with him occurs parenthetically in Wilfred Owen's "The Five Chances," written entirely in the Cockney dialect that belonged to the infantrymen and not to their officers:

I mind as 'ow the night afore that show

Us five got talking, ... we was in the know.

'Over the top to-morrer; boys, we're for it.

Firsr wave we are, first ruddy wave; that's tore it.'

'Ah well,' says Jimmy - an e's seen some scrappin'

'There ain't no more nor five things as can 'appen;

Ye get knocked out; else wounded - bad or cushy;

Scuppered; or nowt except yer feeling mushy.'

One of us got the knock-out, blown to chops.

T'other was hurt, like, losin' both 'is props.

An one, to use the words of 'ypocrites,

'Ad the misfortoon to be took by Fritz.

Now me, I wasn't scratched, praise God Almighty

(Though next time please I'll thank him for a blighty)'

But poor young Jim, e's livin' an' 'e's not;

'E reckoned 'e'd five chances, an' 'e's 'ad;

'E's wounded, killed, and pris'ner, all the lot -

The ruddy lot all rolled in one. Jim's mad. (Owen 71)

Clearly here, with sharp irony, a "Blighty" in the sense of a minor or manageable wound, as in Gurney's "Ballad of the Three Spectres," is much the best outcome, the one to be prayed to God for - because simply to survive is merely to have to face the music another time.

Sassoon is one of many who moves easily from the word "Blighty" to the thoroughly negative words "blight" and "blighter." His fierce poem "Blighters" expresses a view that many soldiers at the front seem to have reached, that the majority of those who remained back home in Blighty were thorough "blighters." Tietjen's LanceCorporal in A Man Could Stand Up in the tetralogy Parade's End, asking his commanding officer for a job reference when the war comes to an end, understands that

it was going to be difficult to get jobs after the War. All the blighters who had got out of serving, all the R. A. S. C., all the Lines of Communication men would get first chance. As the 
saying was, the further from the Line the better the pay. And the chance too!

But this is mild-mannered and understated in its criticism compared with Sassoon's poem "Blighters" ironically centred in the music-hall world of Florrie Forde, where the "dear old Blighty" of the classic song is rejected and replaced by a toxic world at home, crudely expressing a vulgar misplaced patriotism:

The House is crammed: tier beyond tier they grin

And cackle at the show, while prancing ranks

Of harlots shrill the chorus, drunk with din;

"We're sure the Kaiser loves our dear old Tanks!"

I'd like to see a Tank come down the stalls,

Lurching to rag-time tunes, or "Home, sweet Home,"

And there' $d$ be no more jokes in Music-halls

To mock the riddled corpses round Bapaume. (War Poems 17)

"Home" and "Bapaume" - the sardonic antithetical rhyming provides shock measurement of the gap between two mutually uncomprehending world.

There is a discernible misogynistic streak, perhaps, in this and other poems by Sassoon about Blighty. It surfaces most clearly in the poem "Their Frailty," - the "frailty" in question that of women, the unvarying rhyme scheme conveying their obsessions:

He's got a Blighty wound. He's safe; and then

War's fine and bold and bright.

She can forget the doomed and prisoned men

Who agonize and fight?

He's back in France. She loathes the listless strain

And peril of his plight.

Beseeching Heaven to send him home again,

She prays for peace each night.

Husbands and sons and lovers; everywhere

They die; War bleeds us white.

Mothers and wives and sweethearts, - they don't care

So long as He's all right. (War Poems 66)

But of course, the specific play on "Blighty" and "blighters" is merely part of a widespread condemnation of the nation at home by 
many of the soldiers in uniform. It sets in early in the war: we find it already three months in, in November 1914, in the letters of Charles Hamilton Sorley, still in training for battle, to be killed within the year at the Battle of Loos in October 1915. Here the attitude towards "Blighty" identified by Robert Graves is already very much in evidence

England - I am sick of the sound of the word. In training to fight for England, I am training to fight for that deliberate hypocrisy, that terrible middle-class sloth of outlook and appalling "imaginative indolence" that has marked us out from generation to generation.

And without yet using the word in its other sense, Sorley in January 1915 draws the same logical consequences as the narrator of Owen's "Five Chances": "It looks like an affair of years. If so, pray God for a nice little bullet wound (tidy and clean) in the shoulder. That's the place..." (Glover and Silkin 25, 27).

Turning now to uses of the word "blight" in tragic proximity to "Blighty," Ivor Gurney is once again a major point of reference. His poem "Trees" in Severn and Somme carries an italicised prose motto from what must surely be a letter from the front ("You cannot think how ghastly these battle-fields look under a grey sky. Torn trees are the most terrible things I have ever seen. Absolute blight and curse is on the face of everything"), and then proceeds in Wordsworthian cadences to move away from the Somme he sees in front of him and invoke the Blighty of an imagined Severn of the mind:

The dead land oppressed me;

I turned my thoughts away,

And went where hill and meadow

Are shadowless and gay. (SS 61)

Yet it is Wilfrid Owen who comments most explicitly on the relationship in sound and meaning between the two words when he writes to his mother on May 1, 1917: "If I haven't got a Blighty in this war, I will take good care not to get a Blight, as many have done, even in this Regiment" (SPP 130). And a sense of "blight" was as ubiquitous in the years of 1914-18 as the longing for "Blighty" - it would lead straight to the imagery of T. S. Eliot's The Waste Land.

It is perhaps partly because of all this ambiguity surrounding the word "Blighty" that most of the finest writing about "home" as a real place in the First World War - and there is a good deal of it, much 
of it by women - avoids the term altogether. I move in the remainder of this paper to take a look at one of the finest examples of writing about the reality of home, presented in a series of passages from Helen Thomas's 1931 World Without End included in The Penguin Book of First World War Prose (Glover and Silkin 45-53). These contain a fictionalised account of the last Christmas spent at home with her husband, the poet Edward Thomas, on leave before he went to the front to be killed in France. That is to say, writing from the other end of the telescope, from the perspective of a woman at home receiving her man on leave in Blighty for the last time. Its distinctive achievement is the masterly management of time, as it describes in Sekundenstil the agonies and ecstasies undergone by the couple, as the clock ticks down to the final farewell, underlining the extreme fragility and ephemerality of bliss at home in a time of war.

Thus, it invokes, first of all, the quasi-supernatural associations of "Blighty" - the "angels and archangels" of the passage from The Marsden Case. The fictional "Jenny" has been told that her husband 'David' will not be there for the festive season:

But a miracle happened. Suddenly this Christmas of all Christmasses became the most joyous; the snow-bound forest sparkled like Aladdin's Cave; the house was transformed into a festive bower of holly and ivy and fir boughs, and our listlessness was changed into animated happiness and excitement. David after all was coming home for Christmas! (Helen Thomas 172)

The announcement of this nostos energises the whole family as it now breaks out of torpor and gloom to prepare to celebrate the occasion of a lifetime. In the process, time speeds up:

How we worked all that day to get all ready! I snatched a couple of hours to go to London and do the shopping. I bought for David the best Jaeger sleeping-bag and thick gauntlet gloves and a volume of Shakespeare's sonnets, and for the children a real magic lantern with moving slides, and a special present for each one. I brought fruit and sweets and luxuries we had never tasted before, and wine as well. A frock of David's favourite red was my present to myself, and secretly for the baby the children and I dug a little Christmas tree out of the garden and loaded it with toys and trinkets, and candles ready to light. 
Life was not paralysed now, but with new-found vigour sped along eager and joyous. Nor did time stand still. I was up half the night arranging the greenery that the children had ransacked the forest for during the day, and the finishing touches to all that was to make this Christmas of all Christmasses shine above its peer. (Helen Thomas 173)

That is before the festivity itself, of course; thus far, the transcendent associations of "Blighty" are maintained. But with its onset the dreaded moment of departure draws nearer, albeit initially intensifying the urge to celebrate family life. That speeding-up now appears completely double-edged:

The last two days of David's leave had come. Two days and two nights more we were to be together, and I prayed in my heart, "Oh, let the snow melt and the sky be blue again!" so that which was spoiling those precious hours would lift [...]

Then in the evenings, when just outside the door the silence of the forest was like a pall covering too heavily the myriads of birds and little beasts that the frost had killed - we would sit by the fire with the children and read aloud to them, and they would sing songs that they had known since their babyhood, and David sang new ones he had learnt in the army - jolly songs with good choruses in which I, too, joined as I busied about getting the supper. Then, when the baby had gone to bed, Elizabeth would sit on his lap, content just to be there, while he and Philip worked out problems or studied maps. It was lovely to see those two so united over this common interest.

But he and I were separated by our dread, and we could not look each other in the eyes, nor dared we be left alone together. (Helen Thomas 176-177)

Then, as the writing draws to a climax, becoming more and more intimate, and focussing on the couple alone without their children, there is an inspired shift into the present tense, taking us out of the limited time of the home visit, suggesting its momentary conquest in the act of love:

I sit and stare stupidly at his luggage by the wall, and his roll of bedding, kit-bag, and suitcase. He takes out his prismatic compass and explains it to me, but I cannot see, and when a 
tear drops on to it he just shuts it up and puts it away. The he says, as he takes a book out of his pocket, "You see, your Shakespeare's Sonnets is already where it will always be. Shall I read you some?" He reads one or two to me. His face is grey and his mouth trembles, but his voice is quiet and steady. And soon I slip to the floor and sit between his knees, and while he reads his hand falls over my shoulder and I hold it in mine.

"Shall I undress you by this lovely fire and carry you upstairs in my khaki overcoat?" So he undoes my things, and I slip out of them; then he takes the pins out of my hair, and we laugh at ourselves for behaving as we so often do, like young lovers. "We have never been a proper Darby and Joan, have we?"

"I'll read to you till the fire burns low, and then we'll go to bed." Holding the book in one hand, and bending over me to get the light of the fire on the book, he puts his hand over my breast, and I cover his hand with mine, and he reads from Antony and Cleopatra. He cannot see my face, nor I his, but his low, tender voice trembles as he speaks the words so full for us of poignant meaning. That tremor is my undoing. "Don't read any more, I can't bear it." All my strength gives way. I hide my face on his knee, and all my tears so long kept back come convulsively. He raises my head and wipes my eyes and kisses them, and wrapping his greatcoat round me carries me up to our bed in the great, bare ice-cold room. Soon he is with me, and we lie speechless and trembling in each other's arms. I cannot stop crying. My body is torn with terrible sobs. I am engulfed in this despair like a drowning man by the sea. My mind is incapable of thought. Only now and then, as they say drowning people do, I have visions of things that have been the room where my son was born; a day, years after, when we were together walking before breakfast by a stream with hands full of bluebells; and in the kitchen of our honeymoon cottage, and I happy in his pride of me. David did not speak except now and then to say some tender word or name, and hold me tight to him. "I've always been able to warm you, haven't I?" "Yes, your lovely body never feels cold as mine does. How is it that I am so cold when my heart is so full of passion?" "You must have Elizabeth to sleep with you while I am away. But you must not make my heart cold with your sadness, but keep it warm, for no one else but you has ever found my heart, and for you it was a poor thing after all." No, 
no, no, your heart's love is all my life. I was nothing before you came, and would be nothing without your love. Helen Thomas 180-181)

But the passing of time will not be checked, and so the writing returns to the past tense of narrative, albeit one in which a measure of calm in face of inevitability has been achieved:

So we lay, all night, sometimes talking of our love and all that had been, and of the children, and what had been amiss and what right. We knew the best was that there had never been untruth between us. We knew all of each other, and it was right. So talking and crying and loving in each other's arms, we fell asleep as the cold reflected light of the snow crept through the frost-covered windows.

David got up and made the fire and brought me some tea, and then got back into bed, and the children clambered in, too, and we sat in a row, sipping our tea I was not afraid of crying any more. My tears had been shed, my heart was empty, stricken with something that tears could not express or comfort. The gulf had been bridged. Each bore the other's suffering. We concealed nothing, for all was known between us. After breakfast, while he showed me where his account books were and what each was for, I listened calmly, and unbelievingly he kissed me when I said I, too, would keep accounts. "And here are my poems. I've copied them all out in this book for you, and the last of all is for you. I wrote it last night, but don't read it now [...] It's still freezing. The ground is like iron, and more snow has fallen. The children will come to the station with me; and now I must be off.

We were alone in my room. He took me in his arms, holding me tightly to him, his face white, his eyes full of a fear I had never seen before. My arms were round his neck. "Beloved, I love you," was all I could say. "Jenny, Jenny, Jenny," he said, "remember that, whatever happens, all is well between us for ever and ever." And hand in hand we went downstairs and out to the children who were playing in the snow. (Helen Thomas 182)

Again, the close of the passage is masterly, done in terms of the sounds of the lovers' cries to each other, against the background of a silence punctuated only by the ominous of the train waiting to take the soldier 
away. At first they echo each other, but gradually the echoes fade, and evidently die out altogether, in fatal anticipation of the dread news that will in time bring down the curtain on this fragile moment of "Blighty."

A thick mist hung everywhere, and there was no sound except, far away in the valley, a train shunting. I stood at the gate watching him go; he turned back to wave until the mist and the hill hid him. I heard his old call coming up to me: "Coo-ee!" he called. "Coo-ee!" I answered, keeping my voice strong to call again. Again, through the muffled air came his "Coo-ee." And again went my answer like an echo. "Coo-ee" came fainter next time with the hill between us, but my "Coo-ee" went out of my lungs strong to pierce to him as he strode away from me. "Coo-ee!" So faint now, it might be only my own call flung back from the thick air and muffling snow. I put my hands up to to my mouth to make a trumpet, but no sound came. Panic seized me, and I ran through the mist and the snow to the top of the hill, and stood there a moment dumbly, with straining eyes and ears. There was nothing but the mist and the snow and the silence of death.

Then with leaden feet which stumbled in a sudden darkness that overwhelmed me I groped my way back to the empty house. (Helen 182-183)

I close, in connection with this scene from Helen Thomas's book, with a brief autobiographical note, which in part explains my interest in the literature of the First World War. I do not know who my biological maternal grandfather was, but I believe him to have been a soldier who died in World War One. My mother was born on the $19^{\text {th }}$ July 1917, and the space for the name of the father on her birth certificate is left blank. The only clue to his identity might be that she is given the middle name 'Thomas', ironically enough, and she used to claim that she had no middle name, and her half-sister, my aunt, who died in April 2020 at the age of 96, testifies that girls in the family were indeed not given middle names. My mother was born in Newhaven, the regular port of embarkation from England for the battlefront in France, and soldiers were billeted at her grandmother's house at 2 Elphick Road. It seems probable that this was a place where men who were about to go off to face likely death took whatever chance there came there of love from the women of the house, for both my grandmother and my great grandmother gave birth to the offspring of 
anonymous fathers in those years. And so, my grandmother, too, after a blissful interlude and tearful farewell, may herself have waited for the coming home to Blighty of a lover named Thomas who never returned again.

\section{Works Cited:}

Breen, Jennifer, ed. Wilfred Owen: Selected Poetry and Prose. London: Routledge, 2014. (SPP)

Ford, Ford Madox Ford, The Marsden Case. London: Duckworth, 1923. (MC)

Glover, Jon and Jon Silkin, eds, The Penguin Book of First World War Prose. London: Penguin Books, 1990. (Glover and Silkin)

Graves, Robert, Goodbye to All That, London: Penguin, 2014 [1929]. (Graves)

Gurney, Ivor. Collected Poems, ed. P. J. Kavanagh, Oxford: Oxford University Press, 1984. (CP)

---. Severn and Somme. London: Sidgwick and Jackson, 1917. (SS) Available online at https://archive.org/details/severnsomme00gurn

Available. War Letters, ed. R. K. R. Thornton. Manchester: Carcanet, 1983. (WL)

Kipling, Abaft the Funnel. New York: B. W. Dodge and co., 1909; Amazon Reprint, n.d. (Kipling)

Owen, Wilfred. The Collected Poems of Wilfred Owen. New York: New Directions Publishing, 1964. (Owen)

Pevsner, Bedfordshire, Huntingdon and Peterborough. London: Penguin, 1988. (Pevsner)

Sassoon, Siegfried. War Poems. New York NY: Dover, 2004. (War Poems)

Sorley, Charles. The Letters of Charles Hamilton Sorley. Cambridge: Cambridge University Press, 1919.

Thomas, Helen. As It Was and World Without End. London: Faber and Faber, 1972. (Helen Thomas)

Wilson, Jean Moorcroft. Siegfried Sassoon: The Making of A War Poet: A Biography. Volume One, London: Duckworth, 1998. (Wilson)

Yule, Henry, and A. C. Burnell, Hobson-Jobson: The Definitive Glossary of British India, ed. Kate Teltscher. Oxford: Oxford University Press, 2015. (Yule and Burnell) 


\section{LA NOSTALGIE DU PAYS : LA FANTAISIE DE 'BLIGHTY', LA RÉALITÉ DU FOYER}

Cet essai interroge la fréquence du mot 'blighty' dans le prose et la poésie de la première guerre mondiale pour signifier, à partir des premières lignes dans les tranchées, le monde ô combien désiré du foyer. Mot d'origine anglo-indienne, il a une étymologie populaire, les soldats illettrés ayant transformé 'bilayati,' qui veut dire 'étranger', enquelque chose de plus reconnaissable en anglais; il tire son association de la langue Populaire de la poésie de la première guerre mondiale. Alors que la guerre deviant de plus en plus désespérée, il y a un changement de signification : le mot commence, dans la poésie et ailleurs, à signifier une blessure relativement peu sérieuse, qui permet de rentrer à 'Blighty.' J'étudie ce changement à travers les œuvres de plusieurs poètes, Owen, Sassoon, et Gurney. J'examine aussi l'expérience de 'Blighty' par l'autre bout de la lorgnette, pour ainsi dire, c'est-à-dire, de la perspective des femmes écrivains qui accueillent leur bienaimé pour la dernière fois à la maison en lui disant au revoir pour la dernière fois. Pour illustrer cette écriture, j'ai choisi World Without End de Helen Thomas, le remarquable roman de la veuve du poète Edward Thomas.

Mots-clés : 'Blighty,' la culture anglo-indienne, La première guerre mondiale, la poésie, front de guerre à la maison. 